\title{
PENERAPAN MODEL PEMBELAJARAN TEMUAN TERBIMBING UNTUK MENINGKATKAN HASIL BELAJAR SISWA PADA MATERI LISTRIK DINAMIS
}

\author{
Chandra Titius dan Eidi Sihombing \\ chandratitius@gmail.com \\ Jurusan Fisika FMIPA Universitas Negeri Medan \\ Jalan Willem Iskandar Pasar V Medan, 20221
}

\begin{abstract}
ABSTRAK
Penelitian ini bertujuan untuk mengetahui terdapat atau tidaknya peningkatan hasil belajar siswa pada materi listrik dinamis, peningkatan nilai kompetensi keterampilan siswa dan peningkatan nilai kompetensi sikap siswa setelah menerapkan model temuan terbimbing di kelas $\mathrm{X}$ SMAN 1 Bandar T.A. 2013/2014. Jenis penelitian ini adalah quasi experiment dengan populasi yaitu seluruh siswa kelas kelas X SMAN 1 Bandar T.A. 2013/2014 yang berjumlah 13 kelas. Sampel ditentukan dengan teknik cluster random sampling yang terdiri dari 2 kelas dan desain penelitian ini adalah pre test-post test control group design. Masing-masing kelas berjumlah 30 siswa, satu kelas dijadikan kelas eksperimen dan kelas yang lain dijadikan kelas kontrol. Hasil analisis data kompetensi pengetahuan menunjukkan bahwa terdapat peningkatan hasil belajar siswa pada materi listrik dinamis setelah menerapkan model temuan terbimbing di kelas X SMAN 1 Bandar. Peningkatan hasil belajar siswa ditunjukkan dengan lebih tingginya $n^{-}$ gain siswa yang dibelajarkan dengan model temuan terbimbing yaitu 0,36 artinya 36\% materi terserap siswa, dibandingkan dengan siswa yang dibelajarkan dengan pembelajaran konvensional yaitu 0,26 yang artinya 26\% materi terserap siswa. Peningkatan hasil belajar siswa dengan menerapkan model temuan terbimbing yaitu sebesar 13\% atau kategori rendah. Analisis data kompetensi keterampilan menunjukkan bahwa terdapat peningkatan nilai kompetensi keterampilan siswa dengan menerapkan model temuan terbimbing sebesar $15 \%$ atau kategori peningkatan rendah, sedangkan analisis data kompetensi sikap menunjukkan bahwa tidak terdapat peningkatan nilai kompetensi sikap siswa dengan menerapkan model temuan terbimbing.
\end{abstract}

Kata kunci : Model pembelajaran temuan terbimbing dan hasil belajar 


\section{PENDAHULUAN}

Selain keluarga, pengajaran yang baik adalah faktor terpenting dalam pembelajaran siswa. Pengajaran yang baik itu lebih penting daripada kurikulum, pengaturan ruang kelas, rekan sebaya, pendanaan, ukuran sekolah dan kelas, dan kepala sekolah. Hattie (dalam Eggen dan Kauchak, 2012) mengatakan bahwa penelitian yang menggunakan teknik-teknik statistik rumit menunjukkan bahwa keahlian mengajar mewakili 30 persen varian dalam pencapaian siswa. Angka ini luar biasa sebab satu-satunya faktor yang lebih tinggi adalah para siswa itu sendiri yaitu kemampuan, motivasi, dan lingkungan rumah siswa.

Fokus kegiatan pembelajaran di sekolah adalah interaksi pendidik dan peserta didik dalam mempelajari suatu materi pelajaran yang telah tersusun dalam suatu kurikulum. Dalam melaksanakan kegiatan pembelajaran para pendidik di-samping menguasai bahan atau materi ajar, tentu perlu juga mengetahui bagaimana cara materi ajar itu disampaikan dan bagaimana pula karakteristik peserta didik yang menerima materi pelajaran tersebut. Kegagalan pendidik dalam me-nyampaikan materi ajar selalu bukan karena ia kurang menguasai bahan, tetapi karena ia tidak tahu bagaimana cara menyampaikan materi pelajaran tersebut dengan baik dan tepat sehingga peserta didik dapat belajar dengan suasana yang menyenangkan dan juga mengasikkan (Sagala, 2005).

Berdasarkan hasil observasi yang dilakukan oleh peneliti dengan memberikan daftar pertanyaan kepada 31 siswa, sebanyak 22 orang siswa atau $72 \%$ mengatakan bahwa fisika itu tidak menarik dan sulit, sebanyak 5 orang siswa atau $16 \%$ mengatakan bahwa fisika itu menarik tapi sulit dimengerti dan hanya 4 orang siswa atau $12 \%$ yang mengatakan bahwa fisika itu menarik dan masih mampu mereka mengerti. Data di atas sejalan dengan kurang memuaskannya hasil belajar yang diperoleh siswa di kelas tersebut, hanya 4 siswa yang lulus Ujian Akhir Semester I T.A. 2013/2014.

Pelajaran fisika akan lebih mudah dimengerti apabila guru secara kreatif mengaitkan konsep yang dipelajari dengan contohcontoh yang mudah dijumpai. Sebagaimana yang diungkapkan Purwoko dan Fendi (2008) bahwa kunci keberhasilan belajar fisika adalah menyenangi fisika. Siswa dapat dengan mudah memahami konsep-konsep fisika apabila mereka dapat menemukan contoh-contoh aplikatif dan unik yang dapat ditemukan dalam kehidupan seharihari.

Eggen dan Kauchak (2012) menjelaskan bahwa satu pendekatan mengajar di mana guru memberi siswa contoh-contoh topik spesifik dan memandu siswa untuk memahami topik tersebut adalah model temuan terbimbing. Model ini efektif untuk mendorong keterlibatan dan ketertarikan siswa seraya membantu mereka mendapatkan pemahaman mendalam tentang topik-topik yang jelas. Saat menggunakan model temuan terbimbing, guru memberi siswa contoh yang menggambarkan materi yang guru inginkan untuk dipahami siswa. Kemudian, guru membimbing pikiran mereka saat mereka mengenali informasi penting 
di dalam contoh-contoh itu. Bruner, J. dalam Arends (2012) menyatakan bahwa pembelajaran penemuan (discovery) adalah model mengajar yang menekankan pada pentingnya membantu siswa memahami susunan atau gagasan utama dari suatu materi pelajaran, dibutuhkannya keaktifan siswa untuk terlibat dalam proses pembelajaran dan adanya sebuah keyakinan bahwa pembelajaran sejati muncul melalui penemuan pribadi.

Penulis dalam penelitian ini mengajukan proses pembelajaran yang fokus pada penemuan konsep dari contoh-contoh yang mudah ditemukan dalam kehidupan seharihari dan dirangkum dalam percobaan-percobaan sederhana dengan waktu yang efektif, sehingga siswa mampu memahami konsep yang akan dipelajari.

Berdasarkan latar belakang yang telah dikemukakan, penulis tertarik melakukan penelitian ini dengan tujuan untuk mengetahui terdapat atau tidaknya peningkatan hasil belajar siswa pada materi listrik dinamis, peningkatan nilai kompetensi keterampilan siswa dan peningkatan nilai kompetensi sikap siswa setelah menerapkan model temuan terbimbing di kelas $\mathrm{X}$ SMAN 1 Bandar T.A. 2013/2014.

\section{METODE PENELITIAN}

Penelitian ini dilaksanakan di kelas X SMA Negeri 1 Bandar yang berada di Perdagangan, Kecamatan Bandar, Kabupaten Simalungun pada semester genap tahun ajaran 2013/2014 pada bulan April - Mei tahun 2014. Populasi dalam penelitian ini adalah seluruh siswa kelas X SMA Negeri 1 Bandar yang terdaftar pada semester genap tahun ajaran 2013/2014.

Pengambilan sampel dilakukan dengan teknik cluster random sampling. Dalam penelitian ini sampel terdiri dari dua kelas. Satu kelas terpilih sebagai kelas eksperimen, yaitu kelas yang diajarkan dengan dengan menggunakan model pembelajaran temuan terbimbing pada materi pokok listrik dinamis. Sedangkan kelas yang lain sebagai kelas kontrol, yaitu kelas yang diajarkan dengan menggunakan model pembelajaran konvensional pada materi pokok listrik dinamis.

Desain penelitian yang digunakan adalah desain pre testpost test control group design seperti ditunjukkan pada Tabel 1. Dalam desain ini terdapat dua kelompok kelas, kemudian diberi pretes untuk mengetahui keadaan awal apakah ada perbedaan kemampuan antara kelompok eksperimen dan kelompok kontrol.

Tabel 1: Desain penelitian pre testpost test control group design

\begin{tabular}{|l|c|c|c|}
\hline \multicolumn{1}{|c|}{ Kelas } & $\begin{array}{c}\text { Pre- } \\
\text { test }\end{array}$ & Perlakuan & $\begin{array}{c}\text { Post- } \\
\text { tes }\end{array}$ \\
\hline Eksperimen & $\mathrm{T}_{1}$ & $\mathrm{X}_{1}$ & $\mathrm{~T}_{2}$ \\
\hline Kontrol & $\mathrm{T}_{1}$ & $\mathrm{X}_{2}$ & $\mathrm{~T}_{2}$ \\
\hline
\end{tabular}

(Sumber: Sugiyono, 2009)

Keterangan:

$\mathrm{X}_{1}$ : model pembelajaran temuan terbimbing

$\mathrm{X}_{2}$ : pembelajaran konvensional

$\mathrm{T}_{1}:$ pre-test

$\mathrm{T}_{2}$ : post-test 
Secara ringkas prosedur penelitian dijelaskan dalam Gambar 1.

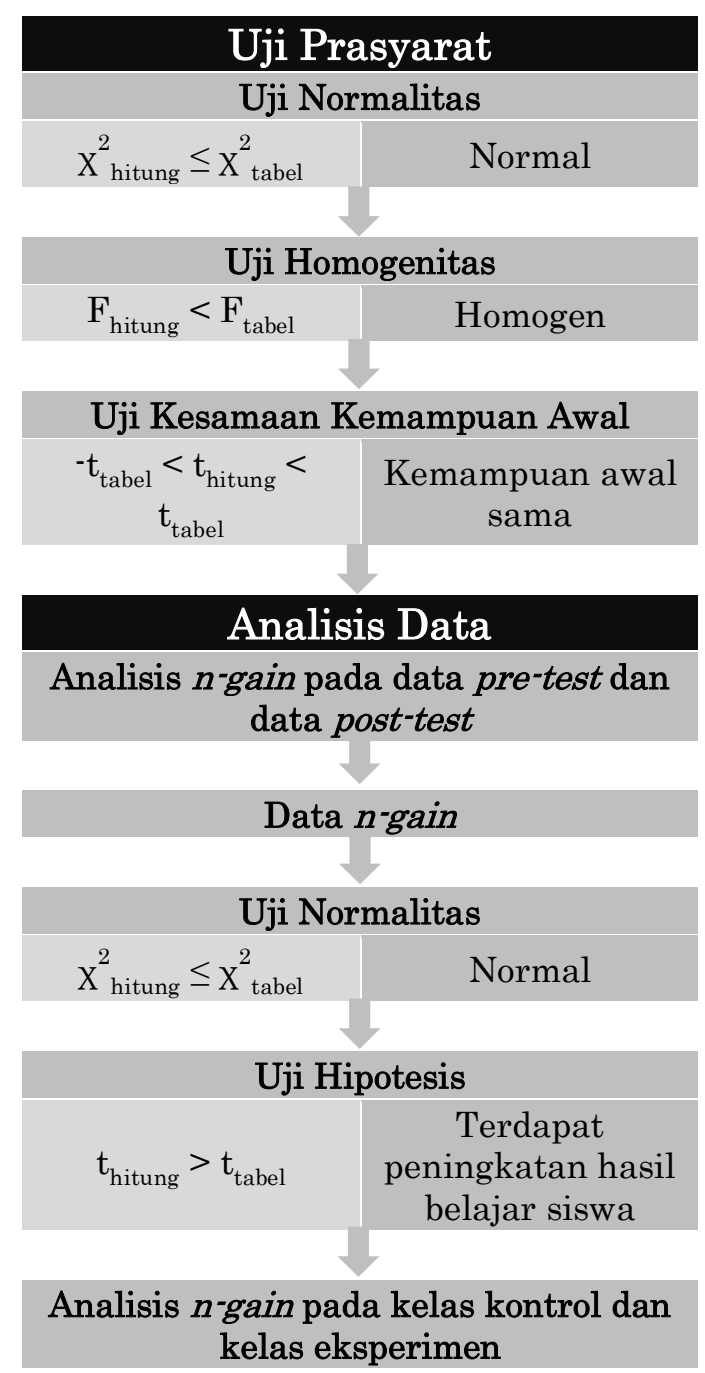

Gambar 1: Prosedur Penelitian

\section{HASIL PENELITIAN DAN PEMBAHASAN}

Distribusi frekuensi nilai pretest divisualisasikan pada Gambar 2.

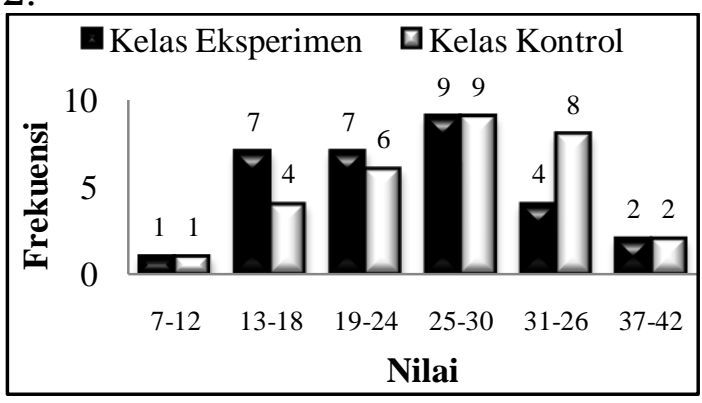

Gambar 2: Diagram batang nilai pre-test
Uji prasyarat dilakukan pada data pre-test. Uji prasyarat yang dilakukan antara lain uji normalitas, uji homogenitas, dan uji kesamaan kemampuan awal yang hasilnya bisa dilihat pada Gambar 3.

\begin{tabular}{|l|c|c|}
\hline \multicolumn{4}{|c|}{ Uji Prasyarat } \\
\hline \multicolumn{4}{|c|}{ Uji Normalitas } \\
\hline Kelas & $\mathrm{X}_{\text {hitung }}^{2} \quad \mathrm{X}_{\text {tabel }}^{2}$ & Kesimpulan \\
\hline Eksp. & $2,23 \leq 11,07$ & Normal \\
\hline Kontrol & $1,17 \leq 11,07$ & Normal \\
\hline \multicolumn{4}{|c|}{ Uji Homogenitas } \\
\hline Kelas & Fhitung $\quad$ F $_{\text {tabel }}$ & Kesimpulan \\
\hline Eksp. & $1,048<1,858$ & Homogen \\
\hline Kontrol & &
\end{tabular}

\begin{tabular}{l|l|l|}
\multicolumn{3}{c}{ Uji Kesamaan Kemampuan Awal } \\
\hline Kelas & \multicolumn{1}{c}{ thitung $\quad$ t tabel } & Kesimpulan \\
\hline Eksp. & $-2,009<-1,108$ & Kemampuan \\
Kontrol & $<2,009$ & awal sama
\end{tabular}

Gambar 3: Uji Prasyarat

Berdasarkan hasil analisis data pre-test, didapati bahwa data berdistribusi normal dan homogen. Data sampel berdistribusi normal mengisyaratkan data memenuhi kriteria untuk uji-t (statistik parametrik) dan data sampel yang homogen menunjukan bahwa sampel mewakili populasi yang juga homogen, sehingga kesimpulan yang diambil untuk sampel mewakili seluruh populasi.

Kelas eksperimen memiliki rata-rata nilai 23,10 , sedangkan kelas kontrol memiliki rata-rata 25,53. Dengan menggunakan uji kesamaan dua rata-rata (uji-t) diperoleh kesimpulan bahwa kompetensi pengetahuan awal siswa sama, artinya walaupun rata-rata hasil pre-test siswa kelas eksperimen dan kelas kontrol 
berbeda tetapi masih dalam rentang yang ditolerir.

Nilai kompetensi pengetahuan siswa setelah diberikan perlakuan direfleksikan oleh hasil post-test. Rata-rata posttest kelas eksperimen adalah 51,10, Sedangkan rata-rata post-test kelas kontrol adalah 45,10.

Data peningkatan kemampuan (hasil belajar) siswa setelah menerapkan model pembelajaran temuan terbimbing dan pembelajaran konvensional diperoleh dari gain score (n-gain) siswa.

Distribusi frekuensi hasil belajar (gain score) kompetensi pengetahuan siswa kelas eksperimen divisualisasikan pada Gambar 4.

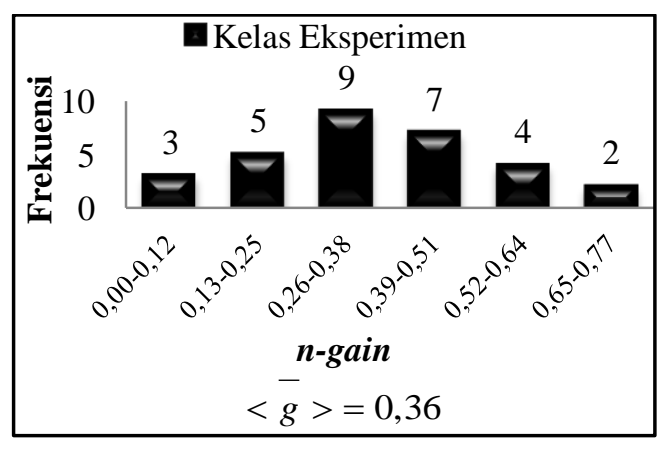

Gambar 4: Diagram batang $n$-gain kelas eksperimen

Distribusi frekuensi hasil belajar (gain score) kompetensi pengetahuan siswa kelas kontrol divisualisasikan pada Gambar 5.

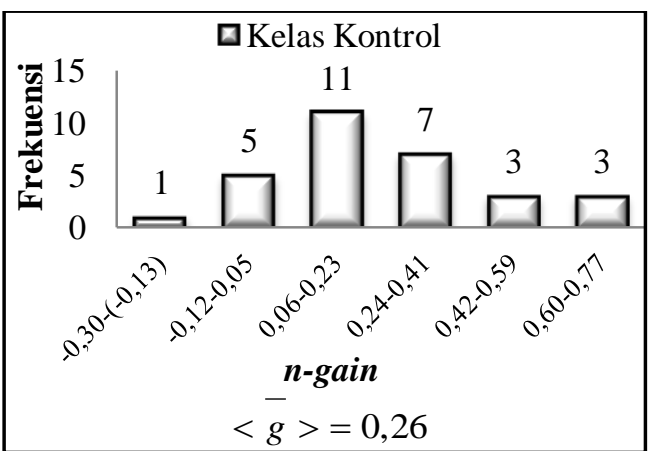

Gambar 5: Diagram batang n-gain kelas kontrol

Analisis data penelitian secara ringkas dapat dilihat pada Gambar 6.

\begin{tabular}{l|c|c|}
\hline \multicolumn{3}{c|}{ Analisis Data } \\
\hline \multicolumn{3}{c|}{ Data pre-test dan post-test } \\
Kelas & \multicolumn{2}{c|}{ Analisis n-gain } \\
$\overline{\mathrm{X}} n$-gain & $\begin{array}{c}\text { Kesimpulan } \\
\text { hasil belajar } \\
\text { sedang }\end{array}$ \\
Eksp. & 0,36 & $\begin{array}{c}\text { hasil belajar } \\
\text { rendah }\end{array}$ \\
\hline Kontrol & 0,26 &
\end{tabular}

\section{Data $n$-gain}

\begin{tabular}{|l|c|c|}
\multicolumn{4}{|c}{ Uji Normalitas } \\
\hline Kelas & $\mathrm{X}_{\text {hitung }}^{2} \quad \mathrm{X}_{\text {tabel }}^{2}$ & Kesimpulan \\
\hline Eksp. & $1,79 \leq 11,07$ & Normal \\
\hline Kontrol & $3,82 \leq 11,07$ & Normal \\
\hline
\end{tabular}

\begin{tabular}{|c|c|c|c|}
\hline \multicolumn{4}{|c|}{ Uji Hipotesis } \\
\hline Kelas & thitung & $t_{\text {tabel }}$ & Kesimpulan \\
\hline Eksp. & \multirow{2}{*}{\multicolumn{2}{|c|}{$1,835>1,672$}} & Terdapat \\
\hline Kontrol & & & $\begin{array}{l}\text { peningkatan } \\
\text { hasil belajar }\end{array}$ \\
\hline
\end{tabular}

\begin{tabular}{|l|c|c|c|}
\hline & \multicolumn{3}{|c|}{ Analisis $\boldsymbol{N}$-gain } \\
\hline Kelas & $\begin{array}{c}\overline{\mathrm{X}} \text { hasil } \\
\text { belajar }\end{array}$ & $n$-gain & Kesimpulan \\
\hline Eksp. & 0,36 & $\begin{array}{c}\text { Peningkatan } \\
\text { hasil belajar } \\
13 \% \text { atau }\end{array}$ \\
\hline Kontrol & 0,26 & & $\begin{array}{c}\text { kategori } \\
\text { rendah }\end{array}$ \\
\hline
\end{tabular}

Gambar 6: Analisis data penelitian 
Berdasarkan rumus n-gain yang dipublikasikan oleh Hake (1999) peningkatan kompetensi pengetahuan siswa atau hasil belajar siswa diperoleh dengan mengurangi nilai post-test siswa dengan nilai pre-test, kemudian dinormalkan dengan membaginya dengan selisih antara maksimum skor yang akan diperoleh dengan nilai pre-test yang pada akhirnya disebut $n$-gain disimbolkan dengan g. Rata-rata $n$-gain siswa yang dibelajarkan dengan model pembelajaran temuan terbimbing sebesar 0,36 dengan predikat peningkatan kompetensi sedang atau $36 \%$ materi diserap, sedangkan rata-rata $n$-gain siswa yang dibelajarkan dengan pembelajaran konvensional adalah sebesar 0,26 atau 26\% materi diserap dengan predikat peningkatan kompetensi rendah.

Sebelum dilakukan pengujian hipotesis, terlebih dahulu dilakukan uji normalitas data hasil belajar ( $n^{-}$ gain). Hasil pengujian data $n$-gain dengan menggunakan uji chi kuadrat memperoleh kesimpulan bahwa data $n$-gain kelas eksperimen dan kelas kontrol normal. Uji homogenitas tidak dilakukan pada data $n$-gain karena telah diuji pada data pre-test dan disimpulkan bahwa sampel berasal dari populasi yang homogen.

Hasil pengujian hipotesis penelitian mendapati $t_{\text {hitung }}>t_{\text {tabel }}$ $(1,835>1,672)$ menunjukkan bahwa rata-rata hasil belajar (n-gain) kompetensi pengetahuan siswa yang dibelajarkan dengan model pembelajaran temuan terbimbing lebih besar dari rata-rata hasil belajar (n-gain) kompetensi pengetahuan siswa yang dibelajarkan dengan pembelajaran konvensional. Artinya, pada populasi yang homogen jika guru yang sama pada satu kelas menggunakan pembelajaran konvensional untuk membelajarkan siswa pada materi listrik dinamis kemudian pada kelas yang lain menggunakan model temuan terbimbing maka hasil belajar ( $n^{-}$ gain) siswa akan meningkat dibandingkan.

Peningkatan hasil belajar siswa dengan menerapkan model temuan terbimbing diperoleh dengan menggunakan rumus $n$-gain yaitu sebesar 0,13 atau 13\%, artinya dengan menerapkan model temuan terbimbing maka hasil belajar/daya serap siswa pada materi listrik dinamis di kelas $\mathrm{X}$ meningkat sebesar 13\%. Meningkatnya hasil belajar (n-gain) siswa akan berbanding lurus dengan meningkatnya kompetesi pengetahuan siswa pada materi listrik dinamis setelah dibelajarkan dengan model pembelajaran temuan terbimbing. Hal ini dibuktikan dengan rata-rata nilai kompetensi pengetahuan siswa di kelas eksperimen yang memang lebih tinggi dari rata-rata nilai kompetensi pengetahuan siswa di kelas kontrol.

Peningkatan hasil belajar kompetensi pengetahuan siswa ditampilkan pada Gambar 7 . 


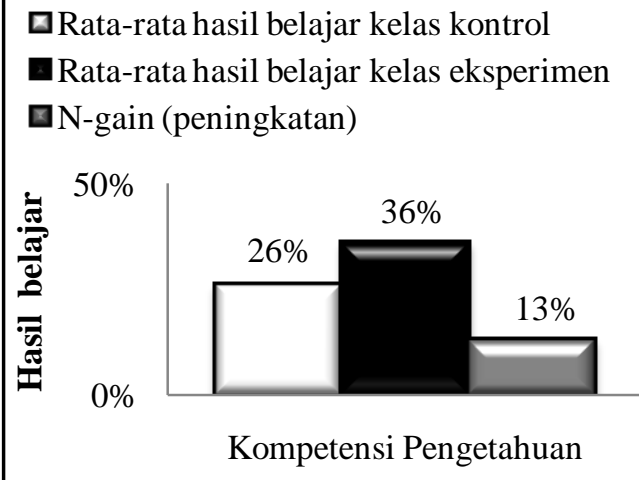

Gambar 7: Diagram batang peningkatan hasil belajar kompetensi pengetahuan

Peningkatan hasil belajar dengan menerapkan model temuan terbimbing disebabkan adanya keterlibatan siswa secara langsung untuk mencari informasi, mengumpulkan data-data, dan menemukan konsep/makna dari apa yang telah mereka peroleh, sehingga siswa tidak disupplay terus menerus dengan pengetahuan akan tetapi lebih cenderung menemukan dan membangun pengetahuan. Belajar menurut teori konstruktivisme bukanlah sekadar menghafal, akan tetapi mengkonstruksi pengetahuan melalui pengalaman. Pengetahuan bukanlah hasil "pemberian" dari orang lain seperti guru, akan tetapi hasil dari proses mengkonstruksi yang dilakukan setiap individu. Piaget (dalam Sanjaya, 2010) berpendapat, bahwa sejak kecil setiap anak sudah memiliki struktur kognitif yang kemudian dinamakan skema. Skema terbentuk karena pengalaman. Proses penyempurnaan skema dilakukan melalui proses asimilasi dan akomodasi. Asimilasi adalah proses penyempurnaan skema dan akomodasi adalah proses mengubah skema yang ada hingga terbentuk skema baru. Semua itu (asimilasi dan akomodasi) terbentuk berkat pengalaman siswa (Sanjaya, 2010).

Hasil penelitian ini sejalan dengan yang dikemukakan Abdisa dan Gestinet (2012) dalam artikelnya yang menyatakan bahwa pembelajaran temuan terbimbing lebih efektif dalam meningkatkan keberhasilan belajar fisika siswa $(<\bar{g}>=0,43$ atau kategori sedang) diikuti dengan metode demonstrasi $(<\bar{g}>=0,34$ atau kategori sedang) sementara metode pembelajaran tradisional kurang berhasil $(<\bar{g}>=0,26$ atau kategori rendah). Hasibuan dan Bukit (2012) dalam artikel penelitiannya menunjukkan bahwa ada perbedaan hasil belajar fisika siswa yang menggunakan model pembelajaran temuan terbimbing dan model pembelajaran ekspositori pada siswa yang memiliki kecerdasan matematik logik tinggi. Siswa yang menggunakan model pembelajaran temuan terbimbing memperoleh hasil belajar yang lebih tinggi yaitu 83, berbanding 72 dengan siswa yang menggunakan pembelajaran ekspositori. Nisa dan Suliyanah (2014) menjelaskan bahwa model pembelajaran penemuan terbimbing dengan mengintegrasikan keterampil-an proses sains berpengaruh positif terhadap hasil belajar siswa. Hasil belajar siswa yang dibelajarkan dengan model temuan terbimbing dengan mengintegrasikan keterampil-an proses sains 80,06, nilai ini lebih tinggi dibandingkan dengan yang menggunakan pembelajaran konvensional, yaitu 61,81.

Rata-rata kompetensi pengetahuan siswa dengan menerapkan model pembelajaran temuan terbimbing belum mencapai KKM 
sekolah (75). Hal ini menunjukkan bahwa hasil belajar siswa juga belum maksimal. Belum maksimalnya hasil belajar siswa menggunakan model pembelajaran temuan terbimbing salah satunya akibat kurang maksimalnya manajemen waktu, terutama yang peneliti rasakan kurangnya waktu pada fase konvergen, sehingga pengarahan menuju konsep yang menjadi fokus pada saat pembelajaran kurang kuat. Siswa lebih banyak menghabiskan waktu untuk melakukan praktikum pada fase berujung-terbuka karena siswa diwajibkan memperoleh data yang dibutuhkan, sehingga fase selanjutnya terkesan terburu-buru.

Nilai kompetensi keterampilan diperoleh dari observasi keterampilan siswa yang dilakukan ketika proses kegiatan menemukan khususnya ketika berlangsung, melaksanakan percobaan, baik dikelas eksperimen maupun dikelas kontrol oleh pengamat yang telah dilengkapi lembar observasi. Siswa kelas eksperimen mendapat nilai rata-rata 68,57 atau predikat baik, sedangkan siswa kelas kontrol mendapat nilai rata-rata 63,03 dengan predikat yang sama.

Nilai kompetensi sikap diperoleh dari penilaian diri dengan bentuk instrumen yaitu skala penilaian (rating scale) yang diisi sendiri oleh masing-masing siswa dalam bentuk lembar penilaian diri. Siswa kelas eksperimen mendapat nilai rata-rata 75,00 atau predikat baik, sedangkan siswa kelas kontrol mendapat nilai rata-rata 76,57 juga dengan predikat yang sama.

Peningkatan nilai kompetensi keterampilan dan nilai kompetensi sikap di tampilkan pada Gambar 8.

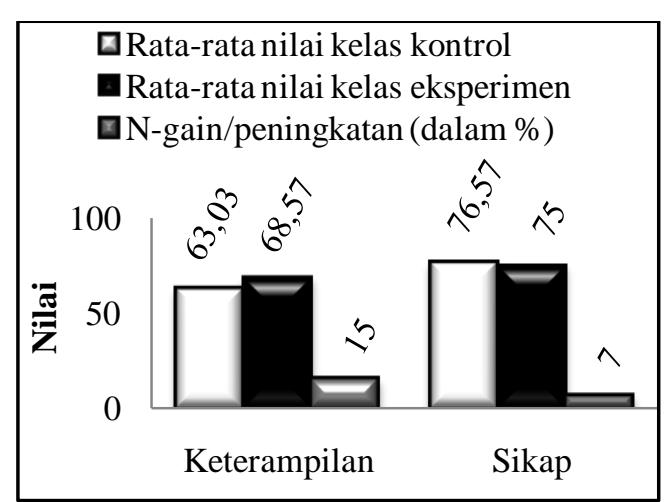

Gambar 8: Diagram batang peningkatan nilai kompetensi keterampilan dan sikap

Rata-rata nilai kompetensi keterampilan siswa kelas eksperimen (68,57 atau predikat baik) lebih besar dari rata-rata nilai kompetensi keterampilan siswa kelas kontrol (63,03 atau predikat baik). Hasil analisis $n$-gain pada nilai kompetensi keterampilan menunjukkan bahwa terdapat peningkatan nilai kompetensi keterampilan siswa dengan menerapkan model temuan ter-bimbing sebesar 0,15 atau predikat rendah, artinya dengan menerapkan model temuan terbimbing maka nilai kompetensi keterampilan siswa $15 \%$ lebih tinggi dari pada siswa yang dibelajarkan menggunakan pembelajaran konvensional.

Ada aspek penilaian/indikator dari kompetensi keterampilan yang mendapatkan perhatian khusus dalam penelitian ini, yaitu indikator mempresentasikan hasil praktik. Rata-rata nilai kompetensi keterampilan untuk indikator mempresentasikan hasil praktik kelas eksperimen adalah 12,83 dari skala nilai maksimal 100, dan kelas kontrol memperoleh rata-rata nilai 0 . Hal ini terjadi karena idealnya setiap kelompok harus mempresentasikan hasil praktik 
mereka setiap satu kali melakukan praktikum, akan tetapi mempertimbangkan minimnya waktu $2 \mathrm{x}$ 45 menit dan adanya lagi fase konvergen dan fase penutup maka dalam penelitian ini hanya 1 kelompok yang mempresentasikan hasil praktik mereka untuk setiap 1 kali melakukan praktikum atau satu topik praktikum, sedangkan pada kelas kontrol siswa tidak melakukan presentasi karena demikianlah yang biasa terjadi.

Peristiwa di atas menjadi koreksi sekaligus pelajaran bahwa untuk mendapatkan nilai psikomotor yang objektif dan otentik, harus memperhatikan indikator-indikator dan standar yang telah ditetapkan dalam kurikulum dengan jelas dan dilaksanakan dengan semaksimal mungkin.

Rata-rata nilai kompetensi sikap kelas kontrol (76,57 atau predikat baik) lebih besar dari ratarata kompetensi sikap kelas eksperimen $(75,00$ atau predikat baik), walaupun hanya dengan selisih yang kecil. Hasil analisis $n^{-}$ gain pada kompetensi sikap siswa menunjukkan bahwa tidak terdapat peningkatan nilai kompetensi sikap siswa dengan menerapkan model temuan ter-bimbing, karena $n$-gain yang diperoleh adalah -0,07, atau menurun dengan predikat rendah. Hal ini bukan menunjukkan bahwa pembelajaran konvensional lebih baik dalam membentuk kompetensi sikap siswa, akan tetapi sikap manusia memang sulit dirubah hanya dalam jangka waktu yang singkat ( \pm 1 bulan, 4 RPP). Seperti yang dikemukakan Garret (dalam Sagala, 2005) bahwa belajar merupakan proses yang berlangsung dalam jangka waktu lama melalui latihan maupun pengalaman yang membawa kepada perubahan diri dan perubahan cara bereaksi terhadap suatu perangsang tertentu.

Sagala (2005) mengatakan bahwa belajar membutuhkan waktu dan tempat. Belajar disimpulkan terjadi, bila tampak tanda-tanda bahwa perilaku manusia berubah sebagai akibat terjadinya proses pembelajaran. Menyikapi hal ini, kompetensi yang bisa diamati mengalami perubahan dalam penelitian ini adalah kompetensi pengetahuan, sedangkan kompetensi keterampilan dan kompetensi sikap perubahannya tidak teramati.

\section{KESIMPULAN DAN SARAN}

\section{a. Kesimpulan}

Berdasarkan hasil penelitian, dapat disimpulkan bahwa terdapat peningkatan hasil belajar siswa pada materi listrik dinamis setelah menerapkan model temuan terbimbing di kelas X SMAN 1 Bandar dengan $n$-gain sebesar 0,13 (13\%) atau kategori peningkatan rendah, terdapat peningkatan nilai kompetensi keterampilan siswa dengan menerapkan model temuan terbimbing sebesar 0,15 atau kategori rendah, dan tidak terdapat peningkatan nilai kompetensi sikap siswa dengan menerapkan model temuan terbimbing.

\section{b. Saran}

Berdasarkan hasil penelitian, pembahasan dan kesimpulan yang dikemukakan menyarankan:

(1) Bagi calon guru dan guru, agar menggunakan model pembelajaran temuan terbimbing maupun model pembelajaran lain yang mendukung 
terbentuknya kompetensi pengetahuan, keterampilan dan sikap, sehingga bisa dilakukan dengan objektif dan memberi hasil yang otentik. (2) Kepada peneliti selanjutnya, agar lebih disiplin dalam penggunaan waktu, jangan sampai waktu yang digunakan berfokus untuk melakukan praktikum pada fase berujungterbuka saja, karena siswa butuh penjelasan dan penyamaan pemahaman (fase konvergen) mengenai apa yang telah mereka praktikkan.

\section{Daftar Pustaka}

Abdisa, G. \& Gestinet, T. 2012. The Effect of Guided Discovery on Students' Physics Achievement, Journal of Physics Education. 6: 530-537

Arends, R. 2012. Learning to Teach. New York: McGraw-Hill

Nisa, C. \& Suliyanah. 2014. Pengaruh Penerapan Pembelajaran Penemuan Terbimbing dengan Mengintegrasikan Keterampilan Proses Sains Terhadap Hasil Belajar Siswa SMP Negeri 1 Kamal. Jurnal Inovasi Pendidikan Fisika 03: 30-34

Eggen, P. \& Kauchak, D. 2012. Strategi dan Model Pembelajaran. Jakarta Barat: Indeks

Hake, R. 1999. Analyzing Change/Gain Scores. Woodland Hills: Dept. of Physics Indiana University

Hasibuan, K. A. \& Bukit, N. 2012. Analisis Pembelajaran Guided Discovery dengan Menggunakan Macromedia Flash Dikaitkan dengan Kecerdasan Logik Matematik
Terhadap Hasil Belajar Fisika Siswa SMAN 1 Kota Subulussalam. Jurnal Penelitian Inovasi Pembelajaran Fisika, 4: 20-25 Purwoko \& Fendi. 2008. Fisika 1 $S M A$ Kelas $X$. Jakarta: Yudhistira

Sagala, S. 2005. Konsep dan Makna Pembelajaran. Bandung: Alfabeta

Sanjaya, W. 2010. Kurikulum dan Pembelajaran. Jakarta: Kencana

Sugiyono. 2009. Metode Penelitian Pendidikan. Bandung: Alfabeta 